\title{
A POSSIBLE RING FORT FROM THE LATE VIKING PERIOD IN HELSINGBORG
}

\section{Margareta \\ Weidhagen-Hallerdt}

\begin{abstract}
This paper is based on the author's earlier archacological excavations at St Clemens Church in Helsingborg as well as an investigation in 1987 immediately to the north of the church. On this occasion part of a ditch from a supposed medieval ring fort, estimated to be about $270 \mathrm{~m}$ in diameter, was unexpectedly found. This discovery once again raised the question as to whether an early ring fort had existed here, as suggested by the place name. The probability of such is strengthened by the newly discovered ring forts in south-western Scania: Borgeby and Trelleborg. In terms of time these have been ranked with four circular fortresses in Denmark found much earlier, the dendrochronological dating of which is $980 / 98 \mathrm{r}$. The discoveries of the Scanian ring forts have thrown new light on south Scandinavian history during the period $A D$ 950-1050. This paper can thus be regarded as a contribution to the debate.
\end{abstract}

Key words: Viking Age, Trelleborg-type fortress, ring forts, Helsingborg, Scania, Denmark

\section{INTRODUCTION}

Helsingborg's location on the strait of Öresund (the Sound) and its special topography have undoubtedly been of decisive importance for the establishment of the town and its further development. Opinions as to the meaning of the place name have long been divided, but now the military aspect of the last element of the name has gained the upper hand. Nothing in the find material indicates that the town owed its growth to crafts, market or trade activity. Neither has a mint been found 
on the site. A place called Halsinburg is named in the ro7os by Adam of Bremen, and is mentioned as having town-like functions in the deed of gift from the Danish king Canute the Saint in Io85 (Weibull I923). Archaeological sources also seem to indicate that Helsingborg was in royal ownership by the middle of the eleventh century and probably even earlier. The two churches built on Crown land, St Clemens (Weidhagen-Hallerdt I986:I3I-I43) and St Peter (Holmberg I964:I 54f), have namely had, at least to judge by the grave material, a fair-sized population basis already during the first half of the eleventh century and this might indicate even earlier establishment of Christianity in the area. Under the oldest burial layer were also found traces of earlier habitation, and infill from several graves contained potsherds and other finds which probably belonged to a late Viking settlement here.

\section{TRELLEBORG-TYPE FORTRESSES AND RING FORTS}

The archaeological discoveries in Denmark and the Swedish province of Scania during the twentieth century have thrown new light on the picture of south Scandinavian history during the period AD $950-1050$. Of particular importance was the discovery of the four circular fortresses in Denmark: Trelleborg on the island of Zealand (Nørlund \& Jensen 1948), Nonnebakken on the island of Funen (Arentoft 1993), and Fyrkat (Olsen \& Schmidt I977; Roesdahl 1977) and Aggersborg on Jutland (Nørgaard, Roesdahl, Skovmand 1986). Two of these were dendrochronologically dated to c. 980 . The four fortresses appear to have been built in the same period, during an astonishingly short space of time, and according to a strict geometrical plan previously unknown in Scandinavia. They are therefore regarded as having been established for a definite purpose and on the initiative of someone with great power, organisational ability and, not least, eminently good financial resources to invest in these building projects, since they required labourers, building timber and large areas of land.

There is now a certain amount of agreement among Danish researchers that a person with such resources can scarcely at that time have been anyone other than the (sole?) reigning king, Harald Bluetooth, the same Harald who, according to the famous rune stone by the church at Jellinge, "has both united and Christianised the whole of Denmark and Norway" (Roesdahl I $987:$ I 56). The researcher Olaf Olsen thinks, however, that from a chronological point of view there is nothing to hinder the fortresses from having been built instead by Har- 
ald Bluetooth's son, Svein Forkbeard, and then used as training camps for his Viking armies. Other researchers (Stilling I98I; Rosborn 2004) firmly oppose such an interpretation in light of the fact that his battles in England took place much later (987-IOI3). According to Stilling, the greatest significance of the Trelleborg-type fortresses lies in the way they so tangibly testify to underlying cultural and economic growth in an international perspective, where a well-organised centralisation of power led to the consolidation of the Danish kingdom during the late Viking period (Stilling I98I:54f). He emphasises that, even if the fortresses were built on the initiative of Harald Bluetooth, this would not necessarily stop them from being used later by Svein Forkbeard. Other researchers think that the dendrochronological dating of Trelleborg should probably be regarded with a certain amount of scepticism (Nielsen 1990).

As is apparent, the discovery of the Danish fortresses has given rise to a wide variety of scientific discussions and interpretations, and has attracted much attention among present-day historical researchers (Randsborg I980; Roesdahl I980; 1987; 1991; Sawyer 1988). Easily grasped summaries of the fortresses and varying interpretations have, for instance, been put together by the researcher Niels Peter Stilling in I9 8 I and, more recently, by Sven Rosborn in 2004. The discovery of related fortresses on the Swedish side of Öresund has given new impetus to debates and book publications in the field. An extremely well documented analysis of the fortress in Borgeby at Löddeköping was published in I999. There the excavators, Fredrik Svanberg and Bengt Söderberg, present a comprehensive interpretation of the whole fortress complex, with special focus on Borgeby, as well as guiding principles for a research programme with emphasis on a comparative local perspective covering the western part of the province of Scania and southern Scandinavia (Svanberg \& Söderberg 1999).

The first of the fortresses to be discovered and the best preserved was Trelleborg on Zealand, and it is after this monument that the Danish type began to be called a "trelleborg" in order to distinguish it from the usual type of ring fort. Characteristic is its circular shape and the courtyard, symmetrically divided into rectangles and forming an unusual element, while the units of buildings, each consisting of four ranges, had long houses in traditional Nordic style (Mårtensson I 976:4I). In Trelleborg and Fyrkat enough timber was preserved to carry out a dendrochronological analysis, and this showed that the 
trees were felled in the winter of $980 / 98$ I (Bonde $\&$ Christensen I 982 ). This chronological information has proved to agree well with the age of the archaeological finds in all four fortresses (Christiansen 1982). These forts were in use for a decade or two into the eleventh century at the most, after which time they were abandoned and left to decay. Or at least, no clear indications of repairs or rebuilding of the fortresses have been observed. The barrack-like buildings inside the ramparts, as well as the find material, more or less indicate military use, but there are also traces of workshop production which reveal that such fortresses were self-sufficient.

An account of the different Trelleborg hypotheses, which elucidates the age, function and historical significance of the Danish fortresses as well as their probable proprietors and possible pattern models, has been compiled by Niels Peter Stilling (Stilling I 98 I), and in a book published a few years later Else Roesdahl (Roesdahl 1987) has taken up the political and economic situation in Denmark shortly before 980 . Against this background Roesdahl has demonstrated Harald Bluetooth's need to consolidate power and regain both lost territory and prestige. In her opinion the special appearance of the fortresses had to do with considerations of symbolic status. They would have had many different uses, above all when needed in times of emergency, but would also have served as winter camps for the Viking fleet. The crew would have been able to turn out in defence of the king's territory at short notice, either if foreign commanders threatened the Danish borders or when the king himself set out for war and ordered plundering raids (Roesdahl I 987: I 56ff). Impulses for the geometric design of the fortresses could have reached Denmark in different ways. It is possible that the Vikings came across old Roman army camps during raids on England or that, as mercenaries to the Prince of Kiev or the Emperor of Byzantium, they acquired some knowledge of Arabian engineering (Nørlund I948:1 55 ff).

\section{THE EARLIEST MAP OF HELSINGBORG}

The discovery of the Scanian ring forts once again raised the question of whether an early fort had stood in Helsingborg, as the name seems to suggest, and perhaps also in other places round the coast of the province during the troubled Viking period - possibly in association with the early St Clemens churches (Rosborn 2004: 107). The northern plateau, which moreover is the highest and most spacious, situated between the 


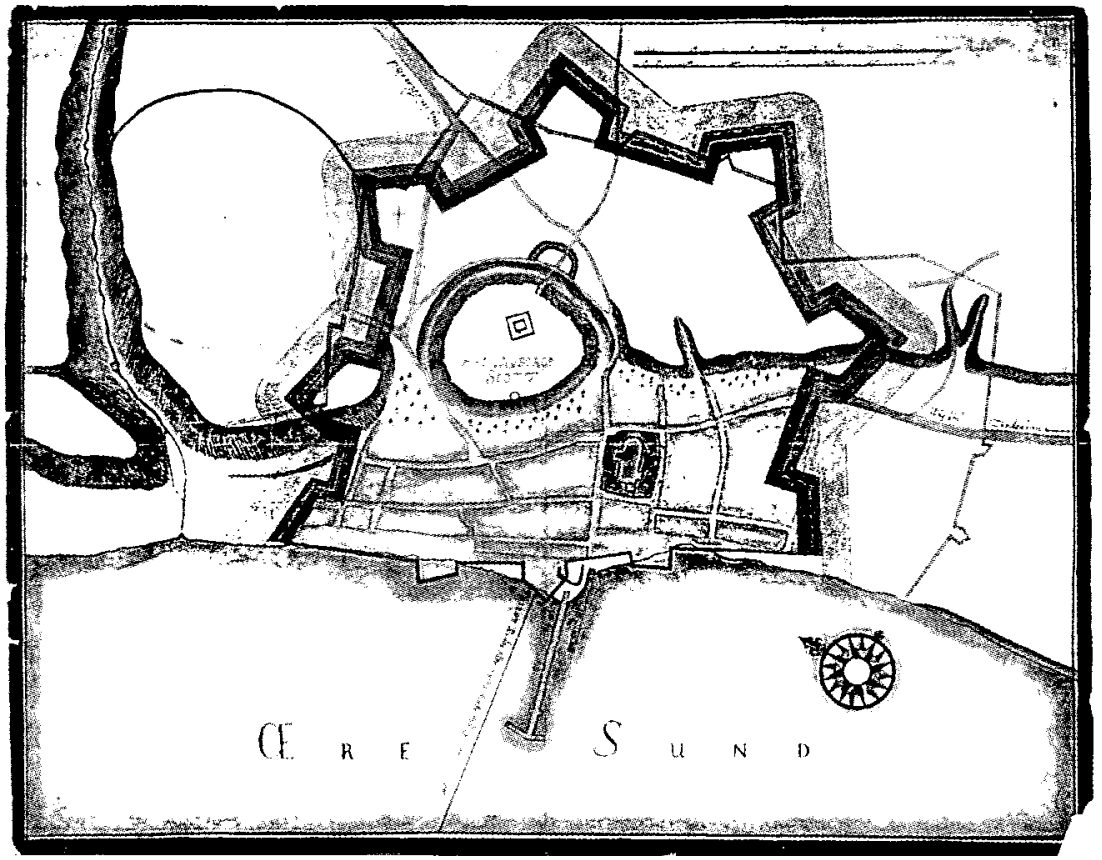

Fig. I. Plan of Helsingborg with proposals for fortifications from 1644 . Notice to the left of the picture the semicircular curving outline with a thinner, parallel line outside this. The circle is completed with broken lines as is the east road at the top. St. Clemens Church is indicated with a cross. (The Fortification Archives, Stockholm.)

deeply cut ravines of present-day Hälsovägen and Långvinkelsgatan, has been regarded by certain researchers (Holmberg 1977:40, 70) as a very suitable place for a fort in Helsingborg. On the oldest known town plan, from the I640s, this very part of the natural defence work is cut off, with a strong, semicircular, curving outline and a thinner, parallel line outside this. The same rampart/indication of a ditch also occurs on later town maps with proposals for fortifications and has puzzled many, including T. Mårtensson, the authority on Helsingborg (Mårtensson I.934:I 5, fig. 19).

\section{NEW INVESTIGATIONS IN THE PRINS FREDRIK QUARTER}

Prior to the I98 7 archaeological excavations in connection with building work in the Prins Fredrik quarter, north of St Clemens Church, there was an air of great excitement since it was now possible to investigate the far end to the north of the churchyard (Weidhagen-Hallerdt I972; Löfgren I988). This area proved to be completely intact despite the comprehensive fortification work that took place here in the 1650 , 


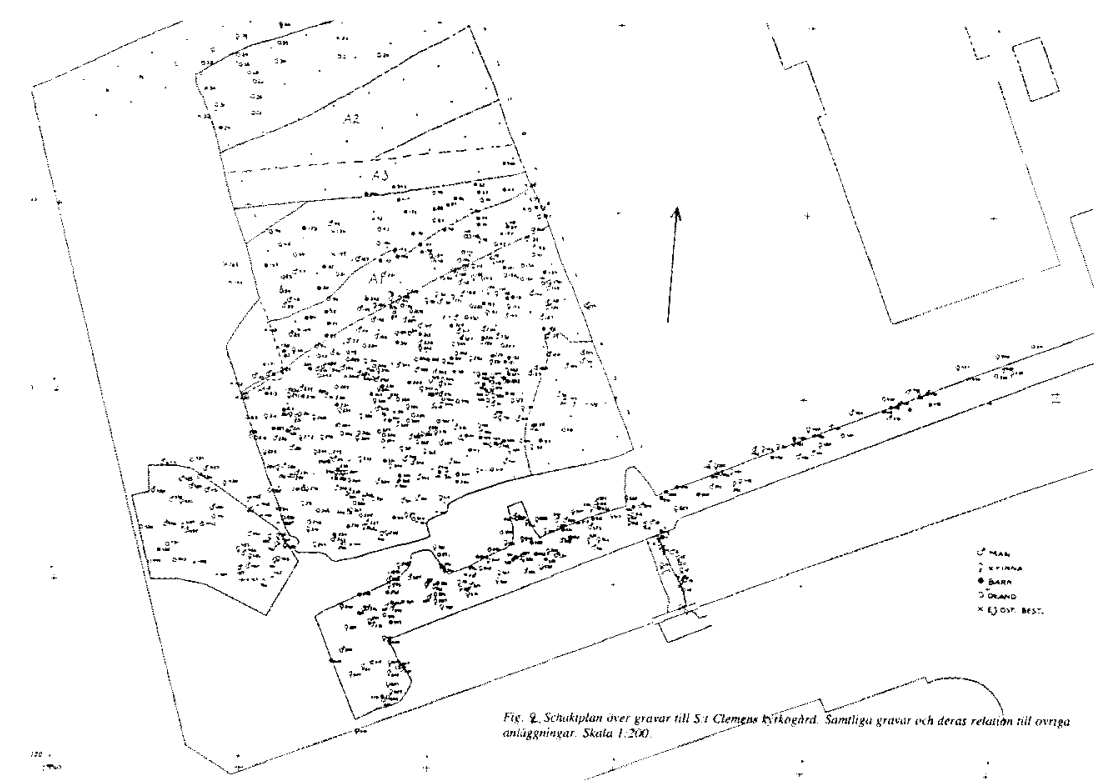

Fig. 2. Excavation plan of the burials of St. Clemens churchyard. All burials and their relationship to other structures such as St. Clemens' Church at the bottom of the plan. Scale 1:200. (Anglert 1996, fig. 9)

when an infill of earth some $2 \mathrm{~m}$ thick had protected the graves. Preservation conditions were bad, however, and only traces of paint and nails bore witness to the fact that wooden coffins had been found. Between 1987 and 1988 , in an area of approximately 480 square metres, more than 600 graves with an east-west orientation were discovered, as well as part of a ditch crossed by a dike, a primitive limekiln, and a stone wall which had been added parallel to the ditch. Under the burial layer various pits and hearths came to light, the earliest being from the Neolithic (Anglert I996:20f, figs. 3, 9).

The largest coherent area of investigation was some 400 square metres. It encompassed more than 400 graves, $20 \%$ of which had nails or obvious paint from wooden coffins, and there were also a small number of stone coffins and graves marked with a few stones. Crossing the excavated area (fig. 2), which was $16 \mathrm{~m}$ wide and $25 \mathrm{~m}$ long, was a dry-stone wall approximately $\mathrm{I} .25 \mathrm{~m}$ wide, which had later been broadened out along the south side to $2 \mathrm{~m}$ but now only had a single course remaining there. The double wall appeared to be laid directly on the surface of the ground some $33 \mathrm{~m}$ north of the church, from whose orientation it diverged somewhat. Under the oldest part of the wall lay I 8 graves, and under the part to which there had been later additions 
were at least 24 graves. The burials lay close together between the wall and the stone church, sometimes up to four layers deep. They formed a coherent burial area up to the stone wall, which possibly can be dated by coin finds from two of the graves. A man's grave with a wooden coffin (no. 279) from the lower layer of graves contained half a coin from the reign of Sven Estridsen. Possibly the oldest layer of graves and the oldest part of the wall belonged originally to Sven Estridsen's church (Weidhagen-Hallerdt I 986). On the basis of coin finds from the reign of Magnus Eriksson, the added part of the wall could be dated to the period after 1332 , when the church was rebuilt after a fire and the nave and churchyard were at the same time extended westwards.

Various postholes under and in association with the wall were found. Several of them lay in a row close to the south side of the oldest part of the wall and can possibly originate from an earlier boundary line on the site in the form of a fence made of plaited branches. This kind of demarcation of a plot is known, for instance, from the earliest secular building in Lund from before c. 990 (Blomqvist \& Mårtensson I 963:I ro). Perhaps a fence of this type delimited the earliest churchyard belonging to the wooden forerunner of the stone church. Alternatively, the posts might have served as some kind of reinforcement of the stone wall.

The lower layer of burials continued under the wall and up to a ditch, which had the same orientation as the wall. The burials between the wall and the ditch formed only one layer and were also more sparsely arranged than those to the south of the wall. Three of the burials were found lying under a dike $\left(\mathrm{A}_{3}\right)$, which in its turn crossed the stratigraphically older ditch (A2). This had evidently halted the extension of the burials to the north, since these began to thin out nearer the ditch, which therefore ought to be older than the burials. In a grave containing rivets from a boat plank (no. 48) was found a beak-shaped buckle with the remains of leather, while a knife in another grave (no. 49) lay close to the pelvis of the dead. Otherwise there were no finds. The burials were laid in rows of the same type as the burials under the stone church, and the depth of the graves varied between $33.22 \mathrm{~m}$ (in the west) and $34.26 \mathrm{~m}$ (in the east), depending on the slant of the ground.

\section{THE DISCOVERY OF A DITCH}

Five metres to the north and parallel with the wall, a ditch with a trough-shaped cross section some four metres wide (Anglert I996; 
sections $\mathrm{I}$ and 5) appeared in the northern part of the I 6-metre-wide excavation area. The western part of the ditch, which was 2 metres deep, was 32.85 metres over sea level, while the eastern part lay some $80 \mathrm{~cm}$ higher $(=33.65 \mathrm{~m})$. On the other side of the ditch, and with a clear westerly displacement, appeared a smaller burial area comprising I 8 sparsely laid out graves in rows one above the other. The depth of the graves was for the most part the same as for those to the south of the ditch and varied between $33.36 \mathrm{~m}$ (in the west) and $33.86 \mathrm{~m}$ (in the east). The burials nearest the north side of the ditch lay more than a metre away and had no stratigraphical connection with it. The orientation and lack of burial finds would seem to indicate that even here it was a question of Christian burials.

The age of the last described burial ground seems difficult to assess. It appears, however, less probable that the graves belonged to the wooden church $43 \mathrm{~m}$ farther south, that is, to the forerunner of the stone St Clemens Church (Weidhagen-Hallerdt I986). It may instead be a matter of a more westerly burial ground of still unknown size, connected with a possible late Viking period Christianised settlement on the plateau. Perhaps the burial ground had to be moved, as is known from cases in Denmark, because a ring fort was going to be erected on the site. Or perhaps the area during the presumed earliest period of the fortress was used as a temporary burial place - in that case probably before the wooden church was built. In view of the low age of the men buried there and the few women and children, this hypothesis is not wholly improbable. At both Trelleborg and Fyrkat there were burial sites close by, outside of but connected with these fortresses.

\section{INTERPRETATION OF THE DITCH}

In order to date the ditch in the northern part of the excavation area, it must first be identified and placed in context. Initially the ditch was regarded as having a connection with the seventeenth-century fortifications. The levels in the ditch containing finds, however, indicated the Middle Ages, though no more accurate dating than that was possible. Using the oldest town plan of Helsingborg, where the scale is given in Swedish roods, as a starting point, the above named semicircular rampart contour was therefore completed with the aid of a pair of compasses. The circle thus achieved measured 75 Swedish roods in diameter and, recalculated to other measurements, this became $270 \mathrm{~m}$ or 450 Swedish ells, which in its turn is the same as 900 Roman feet. This 


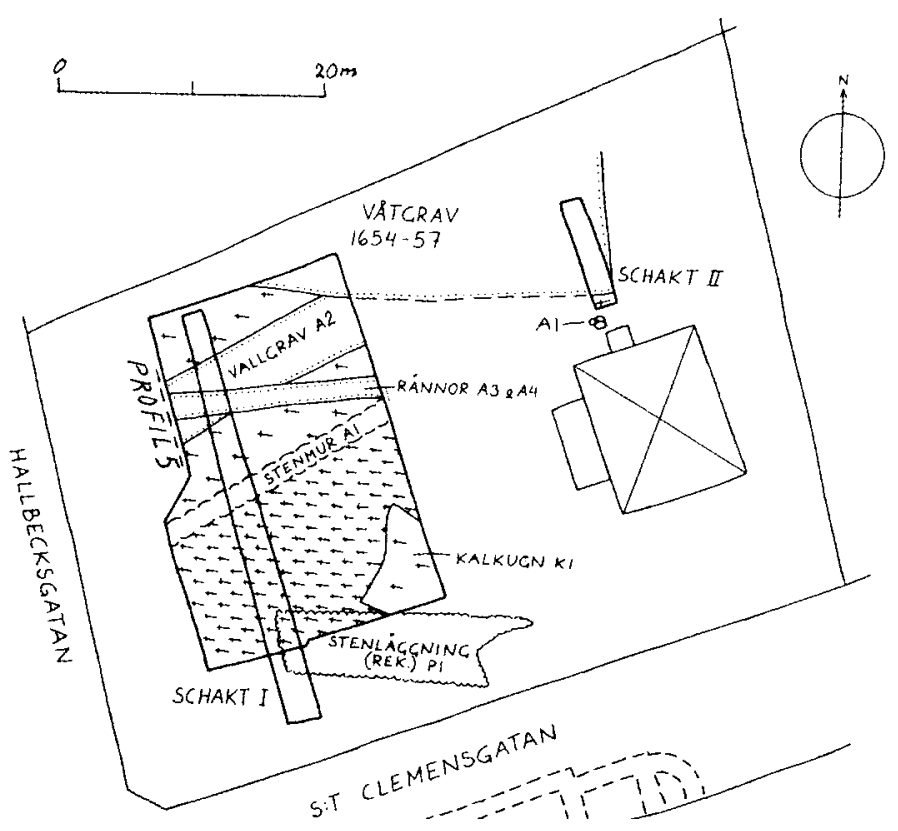

Fig. 3. Site plan showing trench 1 (to the left) with stone wall $\left(\mathrm{A}_{1}\right)$, ditch $\left(\mathrm{A}_{2}\right)$, trenches $\left(\mathrm{A}_{3}, \mathrm{~A}_{4}\right)$, lime kiln $\left(K_{I}\right)$ and pavement $\left(P_{1}\right)$. Profile 5 is marked with broken lines as is St. Clemens Church at the bottom of the plan. (Anglert 1996, fig. 3)

hypothetical ring fort could thus, in terms of measurement, match Aggersborg in Denmark, where the whole fortress plateau is likewise used to its maximum. With respect to a site suitable for a Viking ring fort, even the smaller and somewhat lower plateau containing the medieval fort "Kärnan" has previously been investigated - but the earliest occupation layers connected with this fort were from the middle of the twelfth century (Eriksson et al. 2007).

On a scale adapted to the map, the parts of the ditch and the double wall excavated in 1987 and the church investigated in $1958 / 1962$ were inserted (plan, fig. 3). The measurements and distance thereby corresponded surprisingly well to the archaeological measurements on the site. The slightly concave shape of the north side of the ditch proved to fit exactly into a circle with a diameter of $270 \mathrm{~m}$. The astonishing conclusion then to be drawn was that the ditch found in 1987 might be the first archaeologically verifiable trace of a ring fort in Helsingborg that which nobody thought was possible to prove in view of the enormous fortifications of the seventeenth century. A number of trial pits were dug in connection with the excavation of St Clemens Church in 


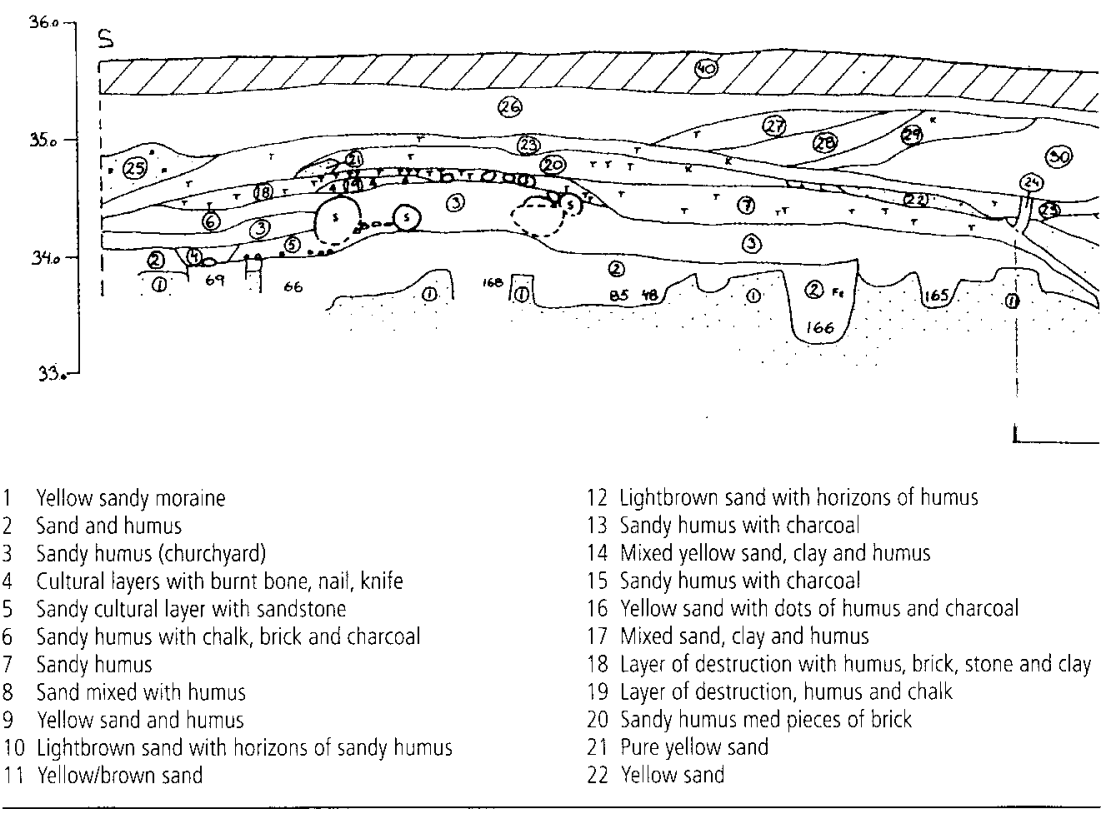

Fig. 4. Section drawing of profile 5 of the ditch facing west. Scale 1:50. (Anglert 1996, fig.38)

the I950s within the presumed southern part of the fort area. It could then be constituted that nothing appeared to remain of any older occupation levels. With the discovery of this ditch, however, new opportunities have opened up, with the possibility of finding traces of a ring fort by extending the section westwards.

\section{HELSINGBORG AND THE SCANIAN RING FORTS}

The ditch found in the Prins Fredrik quarter of Helsingborg shows some of the main criteria for a Scanian ring fort of the type that first turned up in Trelleborg (Jacobsson I 995) and some years later also in Borgeby (Svanberg \& Söderberg I 999:4I). In investigating Scanian ring forts the following five criteria can be stipulated ( $c f$. Borring Olesen 2000:98):

I. A monumental and relatively circular rampart.

2. Rampart built of earth/turf without any inner timber structure, has wooden front with escarp.

3. Gates at four (?) points of the compass with a divergence of approximately 20 degrees.

4. An exterior ditch with a trough-shaped transverse section.

5. A church situated nearby with a burial ground outside the ditch. 


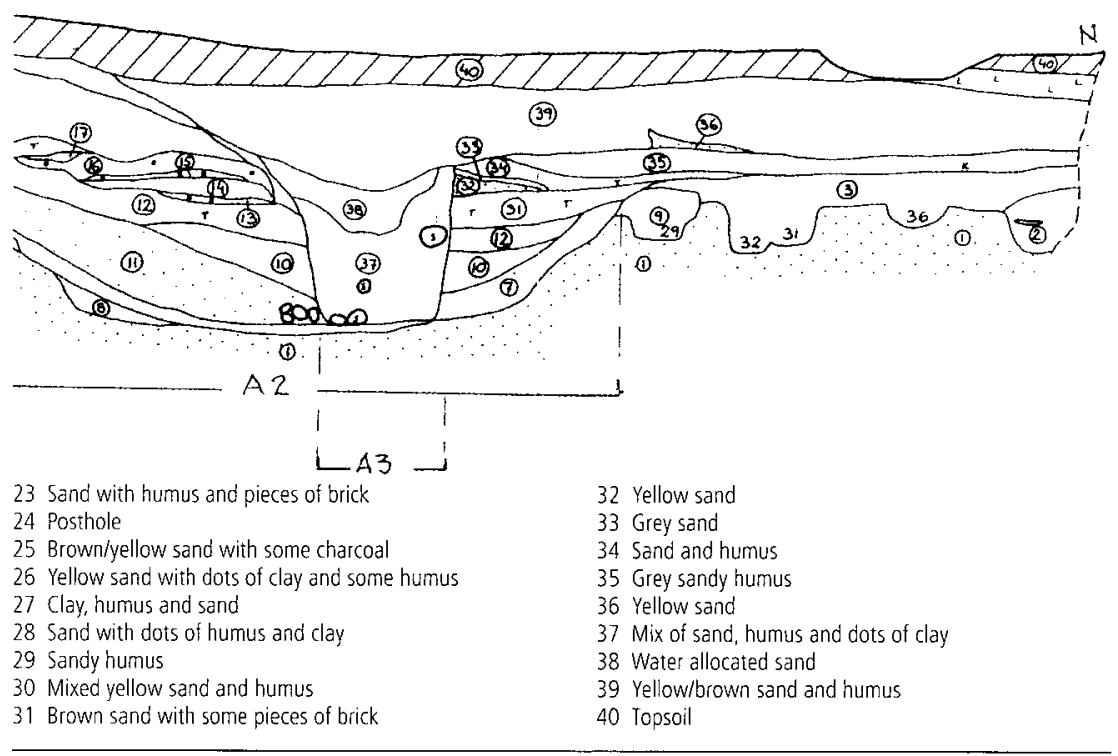

At least three and probably four of the above-named criteria may be seen to be fulfilled in the case of Helsingborg. First of all, the rampart marking on the oldest town plan shows (fig. I) an almost exact semicircle. On the map it is connected with a later fortification wall encompassing the high town and has a different character from the marked rampart. In the second place the existing road markings on the oldest town maps connect with the rampart marking in such a way as to suggest that there would have been at least two entrances. The eastern entrance is marked via the road going in an easterly direction which connects up with the important main route towards Ängelholm and Halland, while the southern entrance is seen to connect up with the main transportation route from the south which has branches both up towards the easterly route already mentioned and down towards the Sound to the west (fig. I). Neither of the two entrances, however, has been positioned in accordance with exact points of the compass, since both seem to have diverged by $20^{\circ}-30^{\circ}$. Whether there were axial streets in connection with these, or buildings inside the fort, will probably never be known considering that the greater part of the high plateau might have been pared away during the fortification work of the seventeenth century. The last two criteria are fulfilled, however, by 


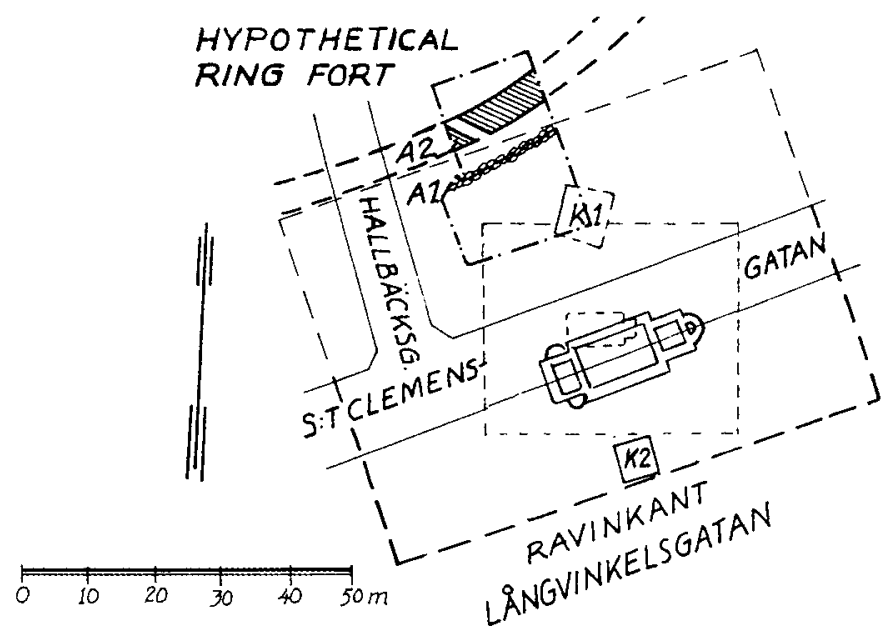

Fig. 5. Plan showing the hypothetical ring fort with the churchyards of St. Clemens and the wooden and stone-built churches all drawn to scale as well as the stone wall $\left(A_{\mathrm{I}}\right)$, $\operatorname{ditch}\left(\mathrm{A}_{2}\right)$ and lime kiln $\left(\mathrm{K}_{\mathrm{I}}\right)$ from the excavation of $1987-1988$ and the lime pit $\left(\mathrm{K}_{2}\right)$ from the excavations of 1958-I960. Scale approximately I: 800 . (MWH/1L)

St Clemens Church, which is situated to the south of the ditch, and by the ditch with its trough-shaped form found in 1987 . Of the five criteria set up for the Scanian ring forts, three, and possibly four, have thus been confirmed, which makes it very probable that a third Scanian ring fort has been found here.

\section{A ZEELAND-FLEMISH PERSPECTIVE}

The two south-western Scanian ring forts showed many similarities with the Zeeland-Flemish ring walls of south-western Holland, above all with the best investigated Oost-Souburg (Trimpe-Burger I 97 5:2 I 7 ) from the end of the ninth century. Common characteristics were the trough-shaped cross section of the ditch and the fact that the four entrances diverged by $20^{\circ}$ from the exact points of the compass. Another common characteristic was the lack of an inner structure of wood, a fact which distinguishes them particularly clearly from the four Danish fortresses, just as does the lack of geometrical division into building complexes. Svanberg and Söderberg (I999:46), on the other hand, have seen the V-shaped as opposed to the trough-shaped form of the ditches as being an all too doubtful criterion for dividing the fortresses into subgroups, particularly since no consideration has been given to lo$\mathrm{cal}$ and geological prerequisites. The researcher Martin Borring Olesen 


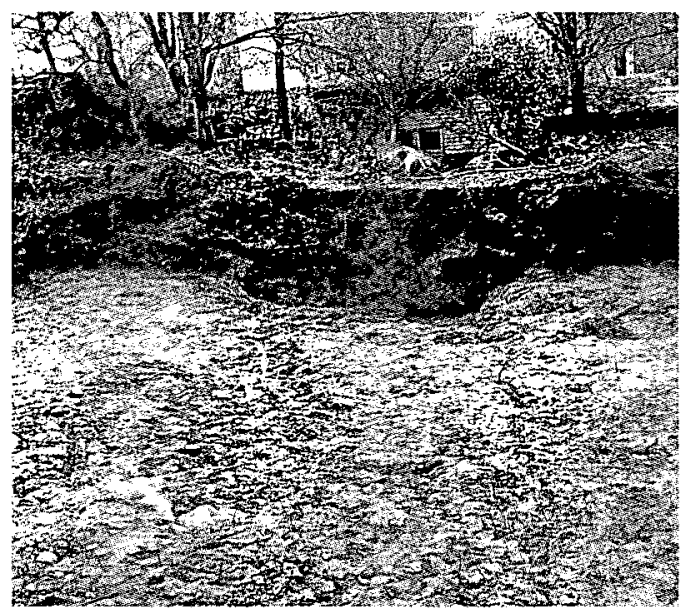

(2000) thinks that the Scanian ring forts ought to be included in a developmental tradition for fortresses encompassing both Zeeland-Flemish ring walls, possibly inhabited by the civilian population either permanently or in times of emergency, and Danish Trelleborg-type fortresses. Further, Sven Rosborn (2004:46) prefers to see chronological parallels between Trelleborg in Scania and Trelleborg on Zealand, but also with Borgeby, because all three fortresses appear to have building phases with common structural characteristics. Leif Chr. Nielsen (I990) thinks that the German conquest of Hedeby in 974 ought to have provided impulses for a series of state initiatives, such as the rapid erection of the Danish circular fortresses seems to bear witness to, and this not only in order to protect Danish trading interests in the Baltic region but perhaps even more with the reconquest of Hedeby in mind, which took place in 983 .

\section{HELSINGBORG AND THE DANISH}

\section{TRELLEBORG-TYPE FORTRESSES}

Since the ditch found in the Prins Fredrik quarter has in all probability been identified as the clearly marked semicircular rampart on the town plan of the I640s, it seems very probable that also Helsingborg has had a complex of the ring-fort type. The question then is whether this was more related to the Danish Trelleborg-type fortresses than with the Scanian ring forts (Borring Olesen 2000). Clearly there are similarities with Aggersborg in Limfjorden with respect to both size and local prerequisites. Aggersborg had an external diameter of 286 
$\mathrm{m}$ (whilst the complex at Helsingborg is some $270 \mathrm{~m}$ ) and an internal diameter of $240 \mathrm{~m}$, making it the largest of the Danish fortresses. Underneath Aggersborg were material remains from the Viking settlers who were apparently forced to leave so that the fortress could be built. As at Fyrkat and Trelleborg, however, no burial ground was found near this fortress; there were only graves connected with the nearby church. The evidently Christian graves found inside the ditch in Helsingborg, on the other hand, would have belonged either to the fort or to an older settlement there, whilst the graves outside the ditch belonged to the church dedicated to St. Clemens (Weidhagen-Hallerdt I986). Both Aggersborg's and Helsingborg's ditches were about $4 \mathrm{~m}$ wide and $2 \mathrm{~m}$ deep, though with a V-shaped cross section at Aggersborg and a trough-shaped one at Helsingborg. But whether there were also similar boat-shaped buildings arranged in rectangles, as at Aggersborg, is something we will probably never know, and this is true to an even greater extent of Nonnebakken.

The Danish circular fortresses were all built according to the same basic geometrical idea and according to definite units of measurement, but nevertheless they show great variation. Important characteristics (Jacobsson I995:49ff) are:

I. Monumental dimensions.

2. An exactly circular fortress

3. Four entrances, one at each point of the compass.

4. Axial streets in association with the entrances.

5. V-shaped ditches, placed a little way outside the rampart.

6. Large hall buildings, forming symmetrically placed rectangles in each quarter of the fortress.

7. The rampart is constructed of earth with an inner wooden framework and a timber-clad facade with inclined timbers (a so-called trelle or escarp).

The circular rampart structure at Nonnebakken with earth and certain elements of turf and a V-shaped ditch are, apart from size, the criteria which form the basis for classifying this fortress as a "trelleborg". Possible traces of the rampart in accordance with the advanced wooden structures built for trelleborgs seem uncertain, just as do the number of entrance gates and their probable positions. The diameter of the fortress site, on the other hand, proved to agree exactly with the I $20 \mathrm{~m}$ 
of Fyrkat. On the whole, the knowledge situation as far as the Danish circular fortresses are concerned seems to be highly variable. The lack of wood at Nonnebakken made it impossible, for instance, to achieve any definite attempts at dendrochronological dating, in contrast to the conditions prevailing at Fyrkat and Trelleborg. But the find material from Nonnebakken has shown that it was constructed in the late Viking period. With respect to its proximity to Odense it is, however, probable that this particular fortress may have had a different use from the others in Denmark, namely the defence of a nearby town.

Returning to the comparison between Helsingborg and Aggersborg, it emerged above that they had almost the same diameter: $286 \mathrm{~m}$ at Aggersborg and approximately $270 \mathrm{~m}$ in Helsingborg. However, since the circular rampart of the latter has not yet been found one knows nothing about its breadth or construction. Further similarities between these fortresses are the placing of a church just outside the ditch and the fact that the distance between the ditch and the church is the same (some $40 \mathrm{~m}$ ). The recently discovered Scanian forts, too, lay in close proximity to churches, while Trelleborg and Fyrkat were connected only with Christian cemeteries which, perhaps, belonged to the fortresses or had been used by earlier settlers. In addition, the fortresses in question were built on comparable high plateaus with the same good opportunities for control of a large and important channel, and both were situated at crossing points for traffic along important transportation routes. Although we still lack precise knowledge of design and construction with respect to Helsingborg, the similarities to Aggersborg as far as size, situation, environment and topography are concerned ought to have some significance for the assumption that a ring fort closely related to Aggersborg could have been found in Helsingborg during the same time period. An extension of the area of investigation north of the ditch may hopefully bring us new and important information.

\section{SUMMARY}

This paper is based on my earlier archaeological excavations at St Clemens Church in Helsingborg as well as an investigation in 1987 immediately to the north of the church. On this occasion part of a ditch from a supposed medieval ring fort, estimated to be about $270 \mathrm{~m}$ in diameter, was unexpectedly found. This discovery once again raised the question as to whether an early ring fort had existed here, as suggested by the place name. The probability of such is strengthened by 


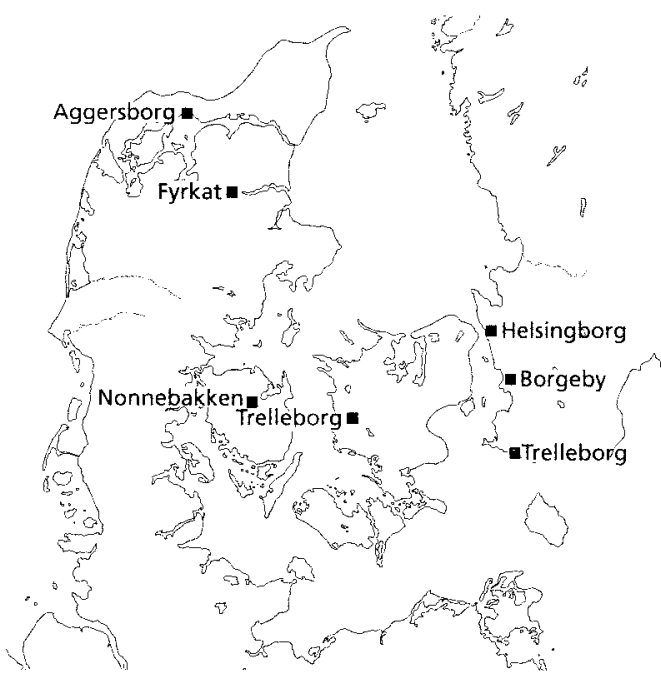

Fig. 7. The Viking ring forts in Denmark and Scania.

the newly discovered ring forts in south-western Scania: Borgeby and Trelleborg. In terms of time these have been ranked with four circular fortresses in Denmark found much earlier, the dendrochronological dating of which is $980 / 98 \mathrm{I}$. The latter are usually known as "trelleborgs" or Trelleborg-type fortresses after the first circular fortress found at Trelleborg on the island of Zealand.

Researchers have long called for a suitable site for a ring fort in Helsingborg, especially in view of the fact that the oldest known town plan from the I640 shows the semicircular marking of a probable rampart/ ditch on the northern and largest high plateau, which is surrounded by deep ravines and which at that time still had flowing water. With the aid of a pair of compasses I have completed the semicircle on the map, where the scale was given in Swedish roods. The diameter of the resulting circle measures 75 roods, which if recalculated comes to $270 \mathrm{~m}$. This means that the whole plateau may have been exploited for a ring fort whose size, environment, geographical location and topography was capable of matching the largest of the Danish Trelleborg-type fortresses, Aggersborg, situated on Limfjord in north-western Jutland.

When the excavated parts of the ditch, a stone wall found at the same time which possibly had adjoined the churchyard to the north, and the earlier investigated stone church in the drawing had been transposed to a scale adapted to the earliest town map, all the measurements and distances were found to correspond surprisingly well to the archaeological measurements on the site. The slightly concave shape of the north 
side of the ditch thus fitted exactly into a circle with a diameter of 270 $\mathrm{m}$. This implies that the ditch excavated in 1987 might well form the first archaeological evidence of a ring fort from the late Viking period in Helsingborg. However, further investigations are needed for a final assessment of the question.

Apart from the newly discovered ring forts at Borgeby and Trelleborg, where the building type diverges from the Danish, the hypothetical ring fort in Helsingborg may be regarded as an important piece of the puzzle in trying to elucidate how the Scanian power elite conducted themselves in relation to the initial attempt of the Danish royal rule to develop a united kingdom during the latter part of the tenth century. The practically contemporaneous ring forts - judging by appearances used only for a short time - would seem to constitute the nearest thing to a powerful means of promoting a united Danish kingdom. This also heralds developments in the other Nordic countries.

The discoveries of the Scanian ring forts have thrown new light on south Scandinavian history during the period AD 950-I050. They have given rise to wide-ranging scientific discussions and reinterpretations, which have attracted much attention among historical researchers not only in Sweden and Denmark but also in the rest of Europe. My paper can thus be regarded as a contribution to the debate.

\section{Translated by Skans Victoria Airey \\ Margareta Weidhagen-Hallerdt, Västerlånggatan 77, I I I 29 Stockholm, Sweden}

\section{References}

Anglert, M. 1996. S:t Clemens kyrkogård. Kv Prins Fredrik 5 och 6, Helsingborg. Arkeologiska undersökningar 1987-1988. Report of UV Syd, Lund. Stockholm: Antikvarisk topografiska arkivet.

Arentoft, E. I 993 . I vikingernes vold. Fynske minder, 1993. Pp. I 1 17-I 41. Odense.

Blomqvist, R. \& Mårtensson, A.W. 1963 . Thulegräuningen i 961 : en berättelse om vad gräuningarna för Thulehuset i Lund auslöjade. Archaeologica Lundensia 2. Lund.

Bonde, N. \& Christensen, K. I982. Trelleborgs Alder. Dendrokronologisk Datering. Aarbøger for Nordisk Oldkyndighed og Historie. Copenhagen.

Borring Olesen, Martin 2000. Trelleborg eller ej? - om den skånske trelleborgs tilknytning til de danske ringborge. Kuml, 2000. Pp. 91-1.1. .

Christiansen, T.E. 1982. Trelleborgs Alder. Arkaeologisk Datering. Aarbøger for Nordisk Oldkyndighed og Historie. Copenhagen. 
Eriksson, T., Drake K. och Carelli, P. 2007. Kärnan och borgen. Helsingborgs slotts medeltida byggnadshistoria. Helsingborg: Dunkers kulturhus.

Holmberg, R. I964. S:t Petri kyrka och kyrkogård. Kring Kärnan. Helsingborgs museums publikation.

- I977. Den skänska Öresundskustens medeltid. Acta Archaeologica Lundensia. Series in $8^{\circ} . \mathrm{N}^{\circ} \mathrm{I}$. Bonn: Habelt.

Jacobsson, B. 1995. Trelleborgen: en au kung Harald Blätands danska ringborgar. Trelleborg: Trelleborgs kommun.

Löfgren, A. 1988. Nya undersökningar på S:t Clemens kỵkogård. Kring Kärnan. Helsingborgs museums publikation.

Mårtensson, A.W.(Ed.). I976. Uppgräut förflutet förPK-banken i Lund:en investering i arkeologi. Acta Archaeologica Lundensia 7. Lund: Kulturhistoriska museet.

Mårtensson, T. 1934. Hälsingborgs slott under medeltiden: ett bidrag till det nordiska borgväsendets bistoria. Dissertation at Lund University. Hälsingborg.

Nielsen, Leif C. 1990. Trelleborg. Aarbøger for Nordisk Oldkyndighed og Historie. Copenhagen.

Norgaard, F., Roesdahl, E. \& Skovmand, R. (Eds.). 1986. Aggersborg gennem Iooo àr: fra vikingeborg til slagtsgård. Herning: Poul Kristensens forl.

Norlund, P. \& Jensen, K. I.948. Trelleborg. Nordiske Fortidsminder IV: . . Copenhagen: Nordisk forlag.

Olsen. O. \& Schmidt, H. (Eds.). I977. Fyrkat: en jysk vikingeborg. 1. Borgen og bebyggelsen. Nordiske Fortidsminder Serie B:3. Copenhagen: Lynge.

Randsborg, K. 1980. The Viking Age in Denmark. The Formation of a State. London: Duckworth.

Roesdahl, E. (Ed.). 1977. Fyrkat. En jysk vikingeborg. II. Oldsageme og gravpladsen. Nordiske Fortidsminder. Serie B:4. Copenhagen: Lynge.

- 1980. Danmarks vikingetid. Copenhagen: Gyldendal.

- ry 87 . Vikingernes verden. Vikingerne bjemme og ude. Copenhagen: Gyldendal.

- r991. The Vikings. London: Allen Lane.

Rosborn, S. 2004. Den skänska historien. Vikingarna. Höllviken: Fotevikens museum.

Sawyer, P. 1988. Da Danmark blev Danmark: fra ca. år 7oo til ca. I o50. Gyldendals og Politikens Danmarkshistorie Bind 3. Copenhagen: Gyldendalske boghandel.

Stilling, N.P. ry8 I. Trelleborgshyporeser. Scandia.

Svanberg, F. \& Söderberg, B. 1999 . Arkeologiska studier kring Borgeby och Löddeköpinge. 1. Den vikingatida borgen i Borgeby. Lund: Riksantikvarieämbetet.

Trimpe-Burger, J.A. 1975. The geometrical fortress of Oost-Souburg (Zeeland). In: Château Gaillard VIl: Actes du colloque international tenu à Blois (France) 2-7 septembre 1974. Pp. 21 5-2.19. Caen.

Weibull, L. 1923. Necrologium Lundense. Lunds domkyrkas nekrologium. Monumenta Scaniae Historica. Lund.

Weidhagen, M. 1972. S:t Clemens kyrka och kyrkogård i Helsingborg. Unpublished M.A. thesis. Lund: Lund University.

Weidhagen-Hallerdr, M. I986. S:t Clemens kyrka i Helsingborg. In: Andrén, A. (Ed.). Medeltiden och Arkeologin: festskrift till Erik Cinthio. Pp. I.3 I-I43. Lund: Lund University. 